\title{
EMPIRICAL STUDY
}

\section{Illuminating Personal Factors Contributing to the Trajectory of Student Dropouts and Stopouts}

\author{
Carlos Nevarez, PhD \& Katrina Pimentel, Ed.D. Candidate, California State University, Sacramento \\ SPONSORED BY: PERSIST: Paving Excellence, Retention, and Success in Student Trajectories, \\ California State University, Sacramento
}

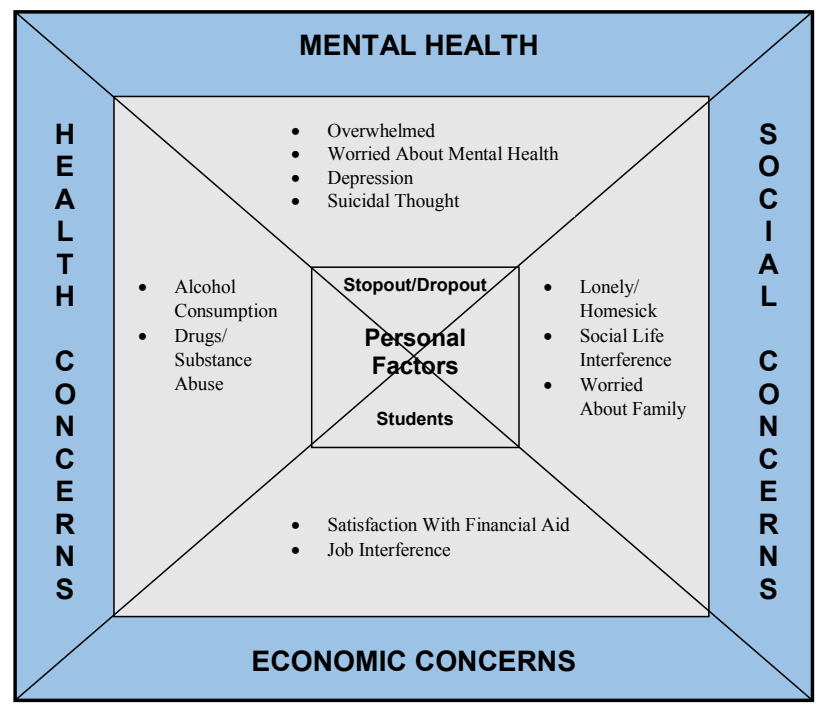

\section{Executive summary}

The purpose of this study was to derive at a comprehensive understanding of what influences students to stopout and dropout at California State University, Sacramento

(Sacramento State). This information aims to inform policy for early prevention and creating effective pathways for increasing student success. To arrive at this goal, a comprehensive research study was undertaken encompassing over 14,000 former undergraduate students who were dropouts (permanent disenrollment) or stopouts (temporarily disenrolled) for one semester, two terms, or a year or more between Fall 2009 through Fall 2015. Five hundred fortynine students responded to the survey.

A guiding objective of this study was to develop a data driven framework to guide Sacramento State in examining practices that serve to facilitate effectiveness in moving

\begin{abstract}
This report is the first of a series of two reports focused on examining the stopout and dropout phenomena at Sacramento State. For the purpose of this study, the data analysis and interpretation centers on highlighting personal issues influencing student departure. Personal issues are defined as the concern with students' mental health, economic, social, and health predicaments. The purpose of this study was to derive at a comprehensive understanding of what mediates students to stopout and dropout at Sacramento State. A guiding objective of this study was to develop a data driven framework for examining practices that serve to facilitate effectiveness in moving students toward degree completion. An important companion to the data analysis and interpretation are the sections on recommendations for action. It is our hope Sacramento State uses the captured sentiment, voices, and suggestions of student participants to improve degree completion. This has policy implications for early prevention, particularly for our most vulnerable students.
\end{abstract}

students toward degree completion. An important companion to the data analysis and interpretation is the sections on recommendations for action. It is our hope Sacramento State uses the captured sentiment, voices, and suggestions of student participants to improve degree completion, particularly among the most vulnerable students. Focus groups were conducted between Spring 2015 to Fall 2016 to seek specific factors that were deterrents to students being able to remain in college. Four key questions were 
asked of these students seeking their input as to why they had dropped out of college, and what resources are necessary for them to return to college to complete their degree. In addition, an online survey was distributed asking for their input on some of the obstacles they encountered while attending Sacramento State. The survey called attention to three areas: personal, academic and demographic obstacles.

The personal section focused on asking questions pertinent to mental health, economic concerns, social concerns, and health concerns. The academic section centered on lack of knowledge, institutional practices, academic skills, and campus culture. The demographics section asked questions about gender, race/ethnicity, number of units taken while enrolled, and the highest education attained by their parents.

This report is the first of a series of two reports focused on examining the stopout and dropout phenomena at Sacramento State. For the purpose of this report, the data analysis and interpretation centers on highlighting personal issues influencing student departure. Personal issues are defined as students' mental health, economic, social, and health concerns.

\section{Introduction}

Students admitted into the university are expected to meet a standard of satisfactory academic progress and performance. While many students are in good academic standing, a considerable number of students fail to do so. Annually, there are over 500,000 students who drop out of college within their first year at the national level. These students tend to be first generation and low-income students which comprise "more than 4.5 million students enrolled in postsecondary institutions - and approximately $24 \%$ of the overall undergraduate population" (Tinto, 2007, p. 8).

Sacramento State has an annual enrollment of 29,349 students, and has an undergraduate underrepresented minority student body comprised of $46 \%$ freshman and $30 \%$ of transfer students. Overall, $51 \%$ of all the students come from low-income families (College Portrait, 2015). According to national data, $75 \%$ of these students will leave within their first year, and less than $30 \%$ of those that left will return to the same institution (Turner \& Thomp-son, 2014). At Sacramento State, for the 2010 cohort, $61 \%$ of incoming freshman returned the second year, while $54 \%$ proceeded to sophomore status by the following year, and $45 \%$ progressed to junior status (University Handbook, 2015).
First year students often face personal, family, academic, and social transitional adjustment issues (Turner, \& Thompson, 2014) and therefore, it is not uncommon for new students and transfer students "to experience feelings of isolation, loneliness and depression in response to having to adjust to bigger class sizes, invisibility, increased competition and the pressure to succeed in more rigorous courses" (Jackson et al, 2013). They may be uncertain about the "right" way to act as college students and begin to question whether they belong and can be successful in college settings (Stephens et al, 2012). This can result in a drop in academic performance and may increase their likelihood of dropping out. The challenges are not only for freshmen, but affect sophomores as well: the "sophomore slump" has been defined as the drop in academic performance as a result of the student's prior academic challenges while struggling to develop autonomy, identity, and purpose (Vuong, Brown-Welty \& Tracz, 2010).

\section{Methodology and Data}

This study consisted of a mixed-methods design. Both quantitative and qualitative data were employed through participant completion of an online survey, focus groups, and interviews. Quantitative data was secured through close-ended (Likert-scale) questions, while qualitative data was acquired through open-ended questions. Survey responses involved the participation of 549 students. Of the students surveyed, a select subgroup of participants volunteered to participate in focus groups. We conducted a total of six focus groups with an average of ten participants per focus group. The survey called attention to three areas: personal, academic and demographic obstacles, while the focus group questionnaire asked the following questions:

1. What was your main reason for leaving Sacramento State?

2. What obstacles/challenges did you encounter while attending Sacramento State?

3. What would it take for you to return to Sacramento State to complete your degree?

4. Are there any additional comments you would like to share concerning your disenrollment from Sacramento State?

Survey data were collected and recorded through CampusLabs (computer-based data program). The quantitative survey responses were analyzed using the Statistical Package for the Social Sciences (SPSS) software. The qualitative responses were analyzed using HyperResearch software. 


\section{Demographics}

Participants were eager to participate and share their college experience. This was particularly evident by their efforts to provide narrative information via the open-ended questions. The following tables (Figures 1 through 5) provide the percentages for participant demographic variables included in the survey (i.e., gender, race/ethnicity, units completed, enrollment status, and parents' level of education). Missing responses are not included.

Figure 1: Gender

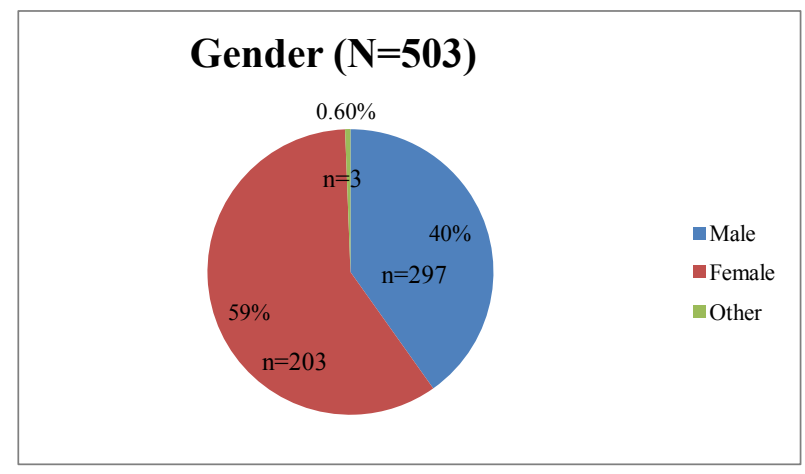

The sample consisted of 549 participants; approximately $59 \%$ of them were female, while approximately $40 \%$ were males. Less than one percent (.60\%) marked other.

\section{Figure 2: Race \& Ethnicity}

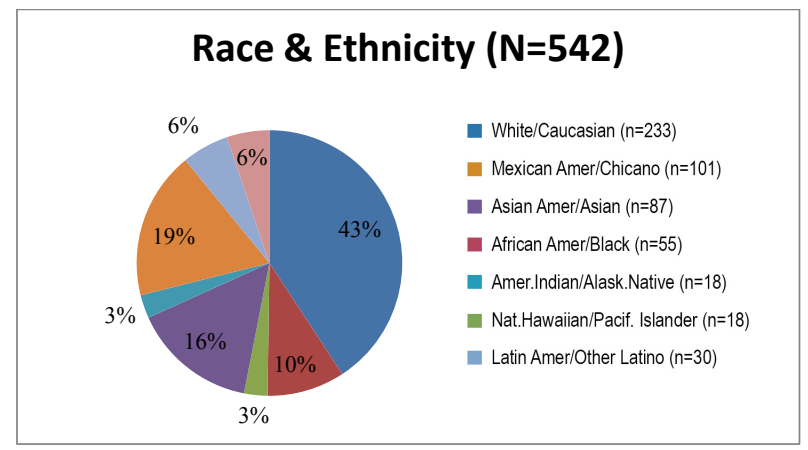

*Students were asked to check all that apply. Therefore, percentages exceed 100.

Approximately 43\% were white/Caucasian, (Non-Hispanic), while the remaining participants were Mexican American/ Chicano (19\%), Asian American (16\%), African American (10\%), Latin America/Other Latino (6\%), Native Hawaiian/ Pacific Islander (3.6\%), American Indian (3.3\%), and Other (6\%).
Figure: 3: Enrollment Status

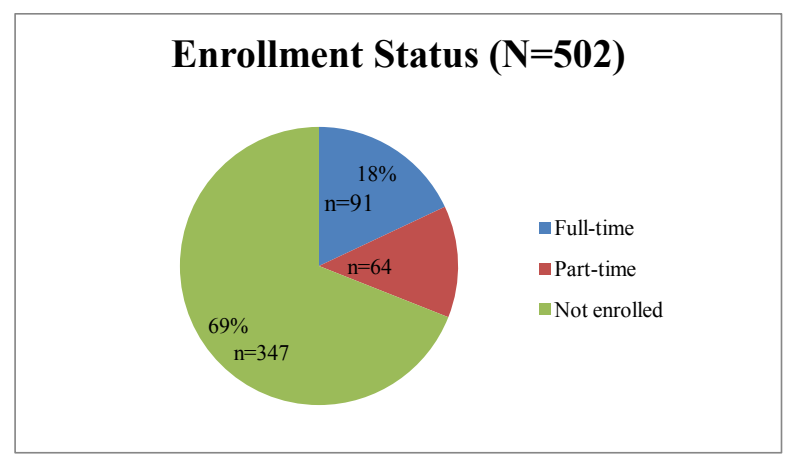

The enrollment status of the sample includes not enrolled (69\%), full time enrollment (18\%), and part-time enrollment (13\%).

Figure 4: Units Completed

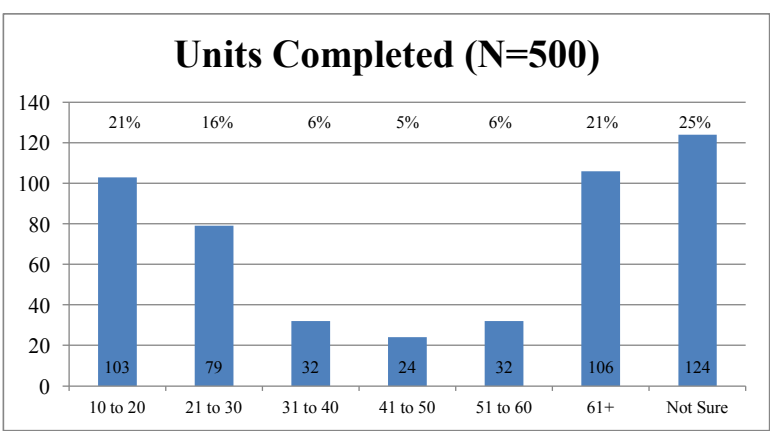

Participants were asked about units completed. The highest percentage includes respondents who were not sure (25\%). Twenty-one percent had completed 61+ units, six percent between 51 to 60 units, five percent between 41 to 60 units, six percent between 31 to 40 units, sixteen percent between 21 to 30 units, and twenty-one percent between 10 to 20 units.

Figure 5: Parents' Level of Education

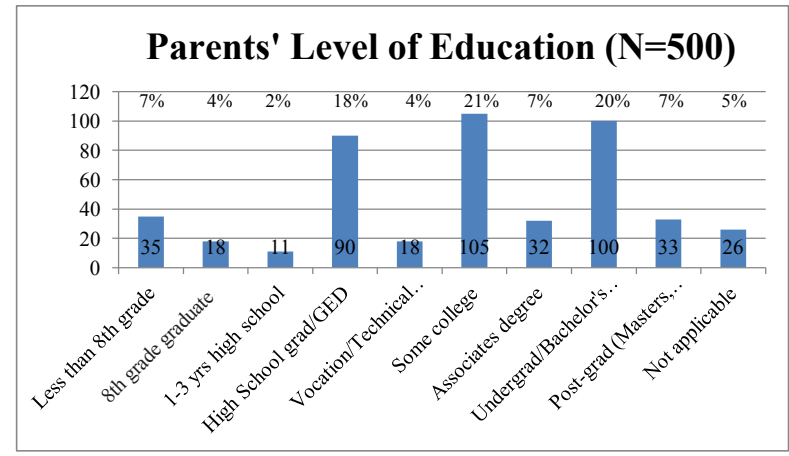

Parents' level of education varied widely with seven percent having less than an 8 th grade education. Eighteen percent had attained their high school/GED diploma, twenty-one 
having secured some college experience, and 7 percent attained their associate's degree. Twenty percent of parents attained their undergraduate degree, with seven percent receiving graduate degrees.

\section{Mental Health OVERWHELMED}

While enrolled at Sac State, how often did you do the following - Feel overwhelmed by all you had to do?

Figure 6: Feeling of Being Overwhelmed

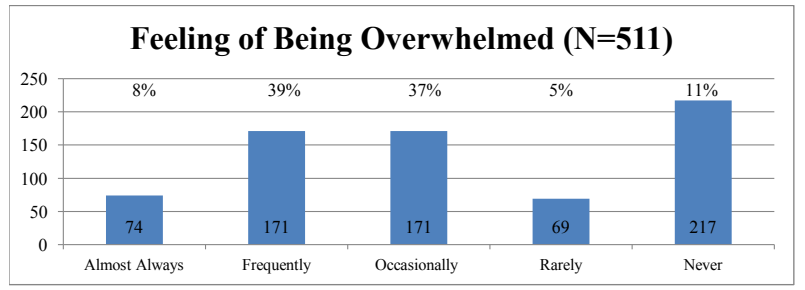

As revealed in Figure 6, 47\% $(n=245)$ of student responses indicated that they almost always to frequently felt overwhelmed. The high response of feeling overwhelmed may be attributed to students not being prepared for college by not having the correct information or guidance in knowing what college entails. Students may think that they have to do it all on their own since they are adults, and may not seek the assistance of services on campus. This sentiment was shared by students in response to the question: What obstacles/challenges did you encounter while attending Sacramento State? One student indicated: "Overwhelmed. I felt prepared going to the university for the classes but not for the workload without any adequate study skills to use. I just constantly fell behind and had no clue how to catch up. I also absolutely and most importantly had no clue how to stay on top of course work and choose classes or interact with counselors or major advisors to help me pick classes. It was basically whatever classes were open I got, and that was neither productive nor helpful towards major completion."

Conversely, $16 \%(n=95)$ of the students responded that they rarely or never felt overwhelmed. Students who fall into this category may be transfer students who have already experienced college life, and are aware of what is expected of them in order to succeed. The following responses indicate that students were able to function without being overwhelmed. One student indicated: "I had some very good teachers for several of my classes who taught the material well and used different media and activities to help the ma- terial sink in and keep us engaged." Another student wrote: "I've never felt so independent in my life. This was once in my life I escaped from the struggles and family problems at home. This taste of freedom and independence felt so amazing. Sometimes I let my freedom get out of hand and I kind of struggled with school work. But it did not affect me as much compared to being stuck at home."

For some students, stress serves as a motivator and improves their academic performance. This was evident in the focus group responses. One student indicated: "Academically, I kind of like having more stresses, more things to do. I am kind of the opposite; if I have less to do I'd do less. If I am worried, I'd do more. So I absolutely am going to do it and don't actually think of it as a big task, and so I am embodied with a lot of work I just function better. I mean I get stressed but I don't get over stressed or angry, but I just start visualizing that I have more to do." Another student indicated: "I also handle stress very well. It doesn't really make me angry. It kind of gets me more focused sometimes, in a weird way. Works as well, so I kind of enjoy the adrenaline rush."

Thirty seven percent $(n=171)$ responded that they sometimes felt overwhelmed. Students could experience certain times throughout the academic year where being overwhelmed is normal, (i.e., meeting deadlines and final exams). How students cope with being overwhelmed during these peak periods is essential to promoting student success. The inability to achieve balance among these demands often precipitates long-term emotional and behavioral changes (Gall, Evans, \& Bellerose, 2000). This feeling of being overwhelmed is expressed by one student: "When I came here, I thought I could keep up with the same amount of courses and I was going at night and I was working during the day, and I was overwhelmed." Another student indicated: "I felt like I was not good enough to be a student in a University. Most people were smarter than me and they get the material more quickly than I do. Maybe the things that college students are supposed to be learning are not getting in my head or they do not stay in my head for long period of time. And whenever I try to find a spot to study on campus, it felt like it's always a scavenger hunt. When I finally find a spot, I'm already exhausted."

\section{Recommendations:}

- Conduct a psychological needs assessment during the admissions process or at orientation. A follow-up assessment should be given to students at the end of each 
academic year in order to be responsive to the changing needs of students as they pursue their degree.

- Continue to emphasize at orientation the importance of accessing available campus academic support such as tutoring and counseling services, as well as stress management workshops available through The WELL. These workshops teach students techniques to cope with the negative emotions and physiological triggers that often accompany performance in areas where they lack confidence and academic skills.

- Continue to develop support groups for students where they can share their feelings and worries with their peers. The support does not have to come through formal meetings or discussions. It can be fun by offering relaxing activities where students can hang out and take their mind off of college.

\section{WORRIED ABOUT MENTAL HEALTH}

While attending Sacramento State, how often did you feel concerned about your mental health?

Figure 7: Worried About Mental Health

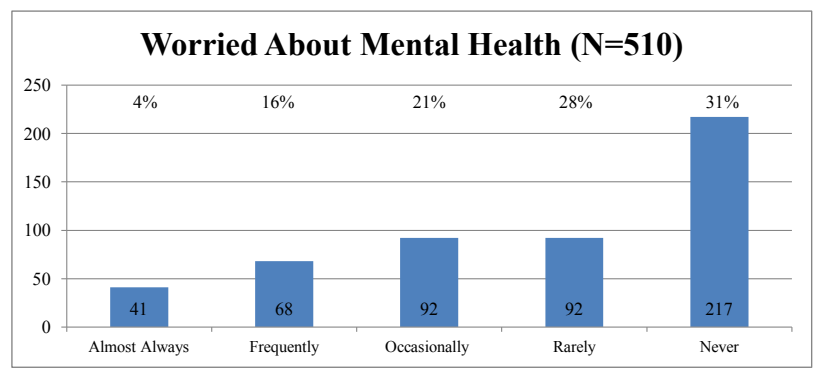

Figure 7 shows 59\% $(n=309)$ of responses indicated that students rarely to never worried about their mental health. This response rate indicates that a little more than half of the students are able to cope with the demands in both their personal life and the university, and are mentally healthy. In response to the open-ended survey question: What strategies do you use to cope with the stressors of daily life? One student indicated: "I can't sing, but I live to sing. If I get into an argument with my daughter or something like that, I go into my room and listen to music. By the time I am done, I don't even remember why I am mad." Other students found that exercise really helped to keep their stress levels down and is evident in the following responses. One student wrote: "I do exercise to relieve stress. Outside of school besides exercise that's all I do." Another student wrote: "Exercise helps me to get my mind off things. Hanging out with family and friends not related to school or work really helps."

In today's demanding college environment, resiliency is critical to academic success. The psychological and emotional struggles of college students have been outlined as important and growing concerns, in addition to a mental health crisis occurring on the nation's college campuses (Kadison \& DiGeronimo, 2004). Each year, approximately one in four Americans experiences a diagnosable mental illness (National Institute of Mental Health, 2006). The majority of these individuals are students who are attending college (Collins, 2000). Recent estimates on the prevalence of mental health issues on college campuses are as high as 30\% (Eisenberg, Golberstein, \& Gollust, 2007).

Conversely, $21 \%$ ( $n=92)$ of students occasionally worried about their mental health. The concern with mental health issues could be attributed to deadlines and exams for students, in addition to outside influences that could affect a student's well-being and mental health, such as working and attending college. Working while in college can be stressful and require students to readjust their schedules in order to get everything completed. Or some students found their choice of major and the university procedures to be an aggravating stressor. For example, one student indicated: "I did not expect the impacted program to be so competitive. In the end it really stressed me out and was not good for my mental health." Another student responded: "I was dealing with a whole bunch of things at the time which was not beneficial to me. All I want is that damn diploma and you guys make it so hard to get. You guys just don't understand the struggle I personally had to go through. I'm not stupid; you can look at my previous grades. But shit happens in life, and you guys just treat every student as a paycheck. I doubt you even care what happens to us. I mean some educators are passion-ate about seeing students succeed. There are some who are going to school to collect money from financial aid and blah blah blah and taking bullshit classes, but there are also students like me, who just want to finish and graduate. But it's almost impossible if it's so hard to get back in, and you guys don't even know half of my story."

Lastly, 20\% ( $n=109)$ of student responses indicated that they almost always to frequently worried about their mental health. According to the 2011 National Survey of Counseling Center Directors (Gallager, 2011), a trend of students 
with severe psychological problems was reported by $91 \%$ of directors (Castillo \& Swartz, 2013). The increasing number of college students with mental health issues has prompted universities to reexamine their campus mental health support policies (Nolan, Ford, Kress, Anderson, \& Novak, 2005). The need to do the same at Sacramento State is evident by one student indicating: "I was not able to get the psychiatric counseling and mental health services that I needed. I was told that I had exceeded the amount of therapy I could receive and that, even though I was considered extremely high-need, there was nothing that could be done for me anymore. My professors were extremely insensitive to mental health issues and showed no concern for me whatsoever. It took years after leaving for me to get back on track."

Based on a national survey, Kessler, Foster, Saunders, and Stang (1995) found that $86 \%$ of students with mental health disorders dropped out of college. This is twice as high as the general college dropout rate, which is estimated to be between 30\% and 40\% (Astin \& Oseguera, 2005; Porter, 1990). Mental health disorders were responsible for several of Sacramento State students' attrition. One student indicated: "My mental and emotional issues (bipolar, PTSD, borderline personality disorder) and the lack of understanding and support from the disabilities department and some professors were a challenge." Another student stated: "The biggest challenge was maintaining good mental health. Throughout most of my time at the college, my mental health was a large concern."

Mental illness remains a personal and stigmatized issue, serving as a barrier to accessing mental health care. Left untreated, persons with mental illness are at a greater risk of experiencing poor mental health outcomes and becom-ing suicidal in the future (Czyz, Horwitz, Eisenberg, Kramer \& King, 2013). The impact of not seeking help for mental health issues was evident in this study. For example, one student indicated: "I would have panic attacks monthly. I slept on average 4 hours a night with naps at school or in my car. I worked about 20 hours a week during college, but school was so demanding it took all of my time. My relationships suffered greatly. I was so stressed out and sleep deprived I lost weight. I still have nightmares about going back to school because of the amount of stress I experienced." Recognizing that mental illness is extremely prevalent among college students, universities can play a major role in transforming perceptions about mental illness (Hunt \& Eisenberg, 2010).

\section{Recommendations:}

- According to the First Year College Experience Report (2013), 53\% of students were not satisfied with the psychological services at CSUS. With the high prevalence of mental health issues affecting college students, and the student narratives in this study, an assessment of campus wide psychological and counseling services is warranted.

- Train university faculty and staff to identify students who perceive a need for help, as many students are reluctant to seek out services in part because of concerns about what others might think because of self-imposed or public-imposed stigma.

- Mental illness stigma reduction efforts (i.e. mental health events and speakers) by the university is needed to promote a culture where help-seeking behaviors and accessing such services are embraced, not shamed.

\section{Depression}

While attending Sacramento State, how often did you feel depressed?

Figure 8: Experienced Depression

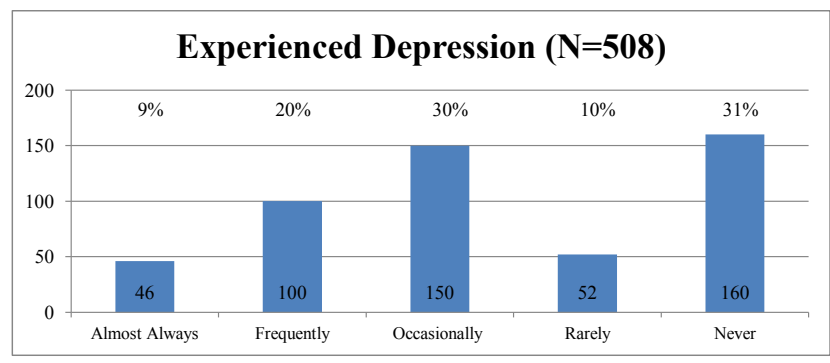

Figure 8 shows that $41 \%(n=212)$ of students responded they had experienced depression rarely to never. While it is normal for students to experience some depression sometimes while attending college, those students who experienced depression on a daily basis are those who are in most need of psychological assistance. As Levine and Cureton (1998) indicated, the stresses and costs that untreated depression places on institutions of higher education are very significant. There is little debate that colleges and universities would benefit from programs that creatively engage their students in positive options for prevention and early detection of depression (National Mental Health Association, 2002). 
Conversely, 30\% ( $n=150)$ of students occasionally experienced depression. These students may have a higher level of self-efficacy and have developed coping strategies that enabled them to effectively manage the challenges encountered without becoming negatively affected by them and is indicative of having a healthy mental state. Some students explicated that their departure from the university was not as a result of a mental health problem, and instead, was a result of a conflict between their personal values and the goals of the university. For example, one student indicated: "I didn't have a reason to be there (depression, anxiety). I didn't have a plan and there is too much focus on getting a degree and not enough on what it takes to get one, leading to significant devaluation of diplomas."

Twenty nine percent $(n=146)$ of students responded that they almost always to frequently experienced depression. Students experiencing frequent depression are more likely to drop out of college if untreated (Astin \& Oseguera, 2005). Community psychology conceptualizes human behavioral problems and solutions as part of a social context (Zax \& Spector, 1974). This perception has led to the view that student depression can best be understood as resulting from the stressful educational environment and in turn can result in poor academic outcomes. This was a sentiment held by many students. When asked the question: What was your main reason for leaving Sacramento State? One student indicated: "I suffer from anxiety and depression. This didn't pair well with my school and work schedule as I worked two jobs and could barely pay my bills or keep up my grades. Unfortunately, the university wasn't the right fit for me at that time." Another student responded: "For me, I hit rock bottom last year and I went through a depression also. I was trying to come back but I was trying to fix myself also and now I am just trying to get back and it is just hard trying to fight for financial aid and everything."

Research on depression among college students revealed that students who were less involved on campus, were more likely to experience depression, especially first generation students (Mehta et al., 2011). This sentiment was shared by one student when asked the question: What obstacles/ challenges did you encounter while attending Sacramento State? One student responded: "I had depression. Lots of it actually. School made me wonder if I would even have a place to live at the end of a semester."

\section{Recommendations:}

- Depression needs to be addressed campus wide in order to raise student awareness about the counseling and wellness services available at Sacramento State in order to support students when they are experiencing depression.

- Provide effective mental health outreach and treatment to students who are showing signs of feeling depressed, or distress with an urgent need for relief.

- Encourage students in distress to enter into treatment where long-term suicide risk could be reduced by psychiatric and psychological interventions.

\section{Suicidal Thoughts}

While attending Sacramento State, how often did you consider suicide or suicidal thoughts?

Figure 9: Suicidal Thoughts

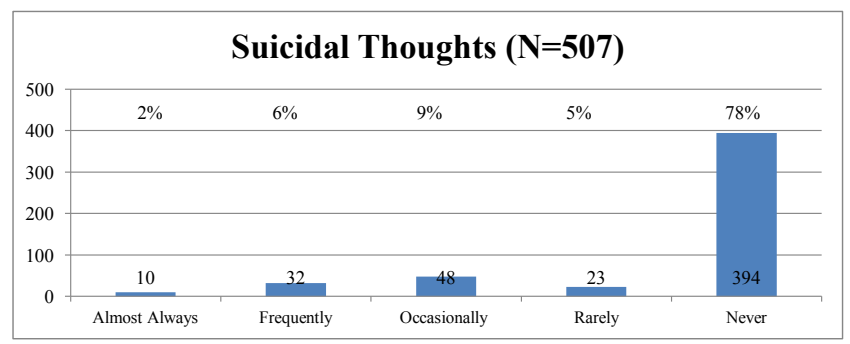

Figure 9 shows that $78 \%(n=394)$ of student responses indicated that they never considered committing suicide. This statistical response clearly indicates that most students were able to attend college without feeling overwhelmed or depressed to the point that suicide would be considered. College student suicide, or attempts at suicide, has become an increasing concern for university officials, faculty, and mental health professionals on college campuses (Haas, Hendin, \& Mann, 2003). Currently, suicide is the third leading cause of death among young adults aged 18-24 (Barrios, Everett, Simon, \& Brener, 2000). Moreover, approximately $24 \%$ of college students have seriously considered suicide, and $5 \%$ reported making a suicide attempt at least once a year (Westefeld et al., 2005).

Fourteen percent $(n=71)$ responded that they occasionally to rarely considered suicide. Again, a closer look as to why students would consider suicide should be explored in future research. If students are thinking in this manner, the underlying issues and triggers need to be addressed. 
Given the perceived importance of obtaining a college degree, avoiding failure, or the impression of avoiding failure, becomes one of the primary goals of college students. For those students who have a difficult time adjusting to college life, establishing failure-avoiding scenarios may be important within the first few semesters of attending college (Covington, 1993). For instance, individuals with adjustment and identity difficulties may delay their transition in order to protect their sense of self-worth (Burka \& Yuen, 1983).

Procrastination is not only an ineffective self-defense, but it is also a self-defeating strategy that may precipitate negative performance, emotional, and behavioral outcomes (Ferrari, 1994, 2001). Specifically, college student procrastination has been associated with low self-esteem (Beck, Koons, \& Milgrim, 2000), emotional distress (Lay, 1995), and self-handicapping behaviors (Ferrari, 1991). However, stress brought on by academic factors, can increase a student's feeling of contemplating suicide. This is confirmed by one student strongly indicating: "The professors were only interested in making us want to commit suicide since they did not teach us anything relevant to the real world and instead failed us even when we diligently attended class and did our work. Corrupt administration still exists in this state's public educational system."

A small percent of students, $8 \%(n=42)$, responded that they almost always to frequently considered committing suicide. Students seriously contemplating suicide may have had other mitigating factors going on in their lives, outside of attending college, which may have added to the pressure. Students who are powerless and living in silence with a mental illness are often unable to see any prospects of a resolution or fail to seek a resolution to their illness, and are at a significantly greater risk of becoming suicidal (Czyz, Horwitz, Eisenberg, Kramer \& King, 2013). The incidence of suicide among college students is a dismal reality, with one study finding that $6 \%$ of undergraduates and $4 \%$ of graduates had "seriously considered" committing suicide (Hunt \& Einsenberg, 2012). The implications to the issue of suicide is that college presents a multitude of stressors for students with courses always culminating with a final exam, project, or paper that can often exasperate students' mental health. Moreover, when someone is suffering mental distress and seriously considering suicide, it may be all-consuming. For example, one student indicated: "Suicide was on my mind 24/7. Caring about my grades was the last thing on my mind." Another student expressed frustration about the bureaucracy of Sacramento State, and was the precipitator to having suicidal thoughts. This student wrote: "Eff corrupt administration, offer students and former students refunds on tuition, abolish diagnostic exams, make classes competency based, give us GPA forgiveness by allowing us to wipe away grades we don't want on our transcripts. STUDENTS ARE NOT GUINEA PIGS FOR YOU TO ABUSE TO DEATH. HOW DARE YOU MAKE US WANT TO COMMIT SUICIDE FOR OUR DEGREES."

\section{Recommendations:}

- Students should have a safe haven where they can seek counseling services should they consider suicide. The campus mental health services and 24 hour suicide prevention hotline should be made visible to students so students can access such services before or during a crisis. Provide educational programs and materials related to stress and suicide to faculty, parents, and to families of incoming and continuing students.

- Faculty and staff should be trained to identify students showing signs of depression or suicidal thoughts and persuade students to seek help. This can include students who have identifiable personal problems and are using one or more ineffective coping strategies. The campus should establish a mental health task force that can oversee the strategic planning process and review on-going efforts.

- Offer general stress-reduction programs on a regular basis, along with non-clinical student support networks. Take a campus-wide approach to address both individual and environmental factors associated with suicide. The entire campus needs to serve an active role in suicide prevention since suicide is a complex problem.

- Resident Advisors (RAs) should be provided with ongoing training to identify signs of mental illness and be responsible for discussing issues regarding suicide issues with students residing in the dorms. If warranted, these assistants should seek psychological intervention if student(s) show signs of anxiety, depression, or having suicidal thoughts. 


\section{Economic Concerns SATISFACTION WITH FINANCIAL AID}

When you were enrolled at Sacramento State, how would you rate your satisfaction with the financial aid services?

Figure 13: Satisfaction with Financial Aid

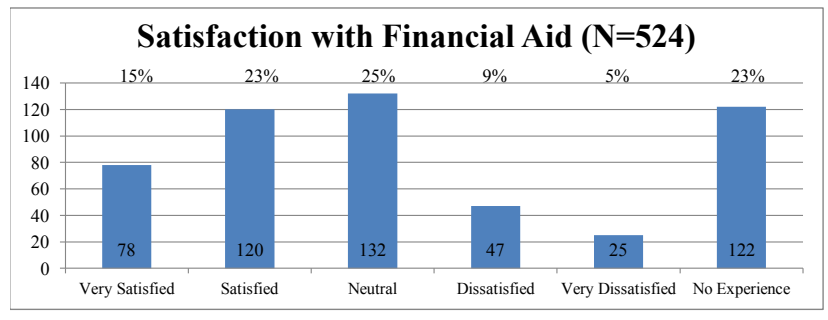

Figure 13 shows that $48 \%(n=254)$ of student responses indicated that they were neutral to having no experience with financial aid. This could be indicative that students were able to finance their education by other means, i.e., parents or other family, scholarships or grants. Financial burdens, college expenses, and overall debt are greater for the millennial student. This is due, in part, to rising costs associated not only for tuition, but for daily living expenses. Students from lower socioeconomic backgrounds, including the majority of first generation students, have been the direct recipients of the shift to the market concept of education, and have had a larger dependence on financial aid, loans and grants (Mehta et al., 2011, St. John, DaunBarnett, \& Moronski-Chapman, 2013).

Traditionally, it has been a goal of financial aid policies to bridge the gap between the family socioeconomic background and college opportunities (McPherson \& Schapiro, 2006). Prior research reveals that different forms of financial aid have distinct and different outcomes on college enrollment, and these results often vary between different subgroups of students (DesJardins 2001; Heller 1999; Paulsen \& St. John 2002). Generally, the research results suggest a positive impact of grants and loans in promoting college enrollments (Heller 1999; Moore et al. 1991); however, this positive effect seems to have different outcomes when taking into consideration student characteristics such as income, age and race (Avery \& Hoxby 2004; Heller 1997). For example, one student indicated: "I am a working adult student attempting to graduate from college now because I had to work when I was younger. It is difficult for me to afford Sac State, but I am not eligible for aid because I make too much money. I feel that there is little support through
Sac State for someone in my position. When I transferred in I felt like the counselors didn't take me seriously as a student because of my age. I had no recourse when I was disenrolled; there was no one to appeal to. I worked hard to transfer in with a $3.9 \mathrm{gpa}$, then I couldn't keep up financially. Work on campus would have helped, but by then I was disenrolled, and so, ineligible. In addition, I drive 65 miles to campus, and so incur more financial and time pressure." If students are unable to secure any form of financial aid assistance, this may deter students from submitting an application and/or enrolling in college.

The increasing gaps in enrollment and the increasing inequality in postsecondary opportunities suggest that financial aid policies mitigate the influence of family income and related socioeconomic factors has not effectively reduced the gaps in college enrollments (Hearn 2001). Student responses to the question why they dropped out of college support this sentiment: "Cost of tuition, as I did not qualify for grants or fee waivers, and had to take out loans to attend. Very costly, and the tuition keeps increasing, making it difficult to return." Another student responded: "I was paying for college myself. My parents did a lot of investment into real estate before the market crash, so while their investments were hemorrhaging funds they still counted against me to get financial aid. I had to work 30 hours a week during school and full time during the summer. When I first attended, it cost $\$ 1600$ a semester. In two years, it doubled to $\$ 3200$. All the while I see new signs being built for aesthetic purposes and a fancy gym. I respect the business decision, but for a school that prides itself on first generation college students and being a commuter college for our working community, I never understood why were put in a position while the costs would increase so drastically. I don't want to drown in student loan debts. So I left. I struggled until I got a job and finished up school online."

Thirty eight percent $(n=198)$ of students indicated that they were very satisfied to satisfied with the financial aid services. This can be interpreted as students who received some form of financial assistance and did not encounter problems in receiving their funds.

Lastly, $14 \%$ of students $(n=72)$ indicated they were either dissatisfied or very dissatisfied with financial aid services. These students most likely encountered a problem receiving their financial aid, had a reduction in their financial aid, or found navigating the financial aid policies to be a challenge. 
When asked the question: What was your main reason for leaving Sacramento State? One student indicated "I think it was the fall of 2012 that the financial aid came and they cut my financial aid package by $\$ 2,000$. And I was living so close to the edge financially. I didn't have that wiggle room, and I was unable to find work to make that up. Then somewhere in February of 2013, was when I reached that point of no return where even if I did find a job there was nothing I could do. I just couldn't be able to make it financially."

For many students, the maximum financial aid award was too low and was a major source of their dissatisfaction. This sentiment is reinforced by one student indicating: "I had three semesters left and the cap on my financial aid had been reached and I didn't even know about the hard cap. I wish someone had told me about that because I could have taken some loans and finished in two semesters, but as soon as that hard cap was reached, I couldn't take out any more Stafford loans and then that was that. I had to borrow money from an aunt to finish the last semester." When asked the question: What obstacles/challenges did you encounter while attending Sacramento State? One student indicated: "The financial aid department was very unhelpful. The department put off processing my application and I never received any kind of financial assistance even after the semester. I ended up paying out of pocket for a class I failed in." Another student indicated: "I was pretty stressed out because I had a part time job while I was going here and I could tell I wasn't doing great because of my grades, but I misunderstood the difference between the SAP (Satisfactory Academic Progress) and the Good Academic Standing and I thought I was OK; but then I realized once it came time that I wasn't going to get the money so..." Another student indicated: "For me, it was hard to ask a question if you don't know what question to ask. So for me I would have never known there's a cap on financial aid unless someone from financial aid could have said there is a cap and you are approaching it. So for me it seems like they are shifting the responsibility to the student who has no clue what is going on and so you rely on experts to give you that information. I wasn't given that information. So students need to be told you are approaching your cap next semester so you may want to look at other options for funding."

The dissatisfaction with navigating financial aid policies was a sentiment held by many. Several students requested that financial aid make their policies more visible and that financial aid advisors communicate with students before the students' standing changes, or before they reach the cap, to avoid delays in receiving financial aid funds or to make other plans to cover tuition and school expenses. For example, one student indicated: "It would be helpful if there is any way to make financial aid requirements and limitations more prominent so we could know and then plan ahead. I know the information is available online, but not highlighted or anything link within a link." "Please let students know when they are about to reach the financial aid cap so they may plan for it."

\section{Recommendations:}

- Having greater access to college costs and financial aid information will increase the likelihood of students applying to college and maintaining retention while enrolled. Efforts to provide detailed financial aid to prospective and current students should be ongoing.

- Knowing when and how financial factors affect a student's departure could increase the efficiency and effectiveness of policies designed to remedy financial related attrition. An improved understanding of what types of financial aid are most effective and how much aid needs to be varied to obtain optimum results could improve aid strategies and make students more likely to succeed.

\section{JOB INTERFERENCE}

While attending Sac State, how often did you feel that your job responsibilities interfered with your school work?

\section{Figure 14: Job Interference}

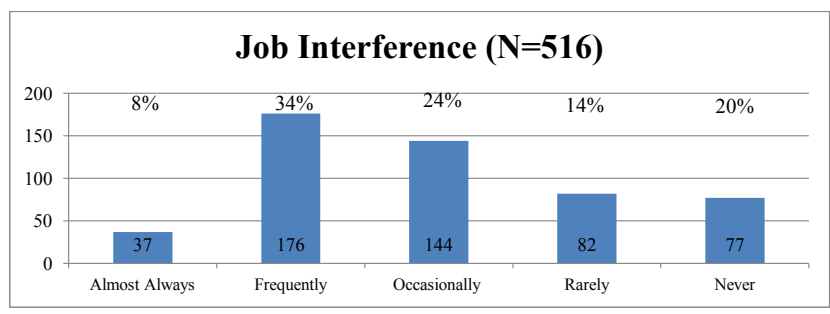

Figure 14 shows that $42 \%(n=213)$ of student responses indicated that working almost always to frequently interfered with their studies. Working extensive hours and going to school can cause a hardship for some students. While some students are able to balance their time between the two factions, others find it difficult to stay on track, particularly due to supervisors not being supportive of the student's educational goals. For example, one student indicated: 
"I came last year in the fall of 2013. I got financial aid, but I still worked a full-time job. It was 35 hours a week. My boss was not supporting my education. He would make me miss school or get fired. So I mean I still needed the money because I was not living with my parents and I was living independently." Another student indicated: "I think the biggest obstacle was I was working. I wasn't working full time, but I was working 32 hours some semesters, and then when I had a fuller load, I had to go down to 24 hours every one or two semesters."

A workload for a full time student is likely to cause elevated levels of psychological and physical fatigue that may undermine an individual's ability or motivation to meet the obligations required of them while attending college (Mortimer et al., 1994). This is verified by one student stating: "It was a little difficult for me to do assignments that required me to interact heavily with other students because of my full time work/school schedule." When asked the question: What obstacles/challenges did you encounter while attending Sacramento State? One student indicated: "As a college student working to pay for tuition, it was extremely difficult to continue my education and work at the same time. I would have to work over 40 hours a week in order to pay for college, which left me with no time to study or attend classes. College should never be so expensive that dedicated students like me can't even afford it. As a country, I almost guarantee that we are leaving so much talent on the table because our greed forces those students out of school."

The $34 \%$ ( $n=159)$ of student responses indicated that they rarely or never were affected by their job responsibilities. Swanson, et al. (2006) suggested that some students are better able to continue to work while attending college because of their experience maintaining jobs during high school and therefore, have mastered the balance between employment and coursework. While there are a number of students who choose to work while attending school in order to maintain their continued lifestyle (Broadbridge \& Swanson, 2005; Curtis, 2007; Holmes, 2008; Swanson, Broadbridge, \& Karatzias, 2006), many students must work in order to provide for basic needs, such as rent, food, and family obligations (Curtis, 2007), particularly those from low socio-economic status who are twice as likely to work when compared to their financially better-off peers (Callendar, 2008). These students are more likely to take out student loans to finance their education, and therefore may continue to work out of concern for post-graduate loan repayment (Curtis, 2007; Watts \& Pickering, 2000). Kulm and Cramer (2006) concluded that student loan debt in the early 2000 s was $85 \%$ higher compared to students who graduated ten years prior (i.e., early 1990s average \$8,200; early 2000s average $\$ 15,100)$.

The continued rising costs of college tuition indicate that many students will need to work to help re-pay their student loans. It is generally assumed that working long hours may affect student achievement, advancement and success because it interferes with a student's ability to meet school related demands and obligations (Steinberg \& Cauffmann, 1995). As one student indicated: "I think mine was I was trying to find stability with working 40 hours and being a single parent." Having to work extensive hours and go to school puts students at a disadvantage." This disadvantage could mean that studies and grades will suffer, while trying to maintain a job that will help support a student's financial obligations. Conversely, $24 \%$ ( $n=144)$ of students responded that their jobs interfered with their studies occasionally. This statistic is indicative that students are working to support their educational goals and daily necessities, and their work positions may interfere with their studies at certain times, perhaps during peak academic demands such as during mid-term and final exams.

\section{Recommendations:}

- Suggestions on how to help working students succeed in college include: offering courses in the evenings, on weekends, and in distance education formats; establishing course schedules in advance; offering students access to academic advising and other support services at night and on weekends; and providing child-care options.

- Students should be taught functional ways of coping with adverse situations, both at school and at their jobs. Inform students how work can interfere with their studies. Encourage the campus to work with employers, both on and off campus, so employers and students are aware that their studies are first priority. Make the workload reasonable with clear goals.

- Intervention strategies such as work-schedule flexibility and job enrichment should be implemented in an effort to maximize the positive and minimize the negative outcomes of employment during the academic year. Creating an institutional culture that promotes the success of working students will require a campus-wide effort that 
involves the university administration. Colleges should encourage, reward, and support faculty members who adapt their instructional practices to promote the educational success of working students.

\section{Social Concerns}

\section{LONELINESS/HOMESICKNESS}

While attending Sacramento State, how often did you feel lonely or homesick?

Figure 10: Experience Lonely/Homesickness

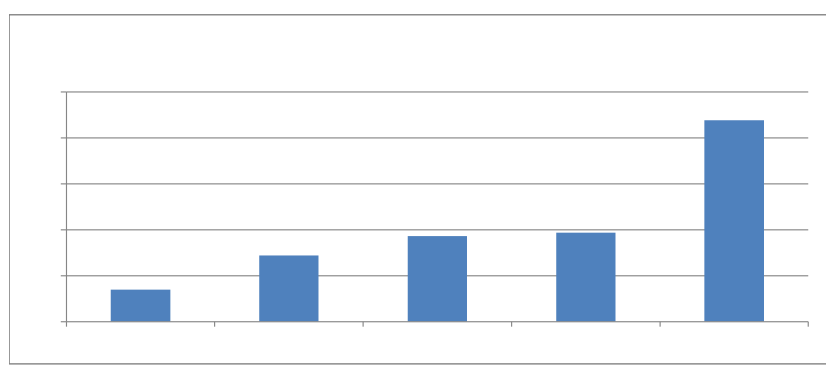

Figure 10 shows that $32 \%(n=219)$ of student responses indicated that they never felt lonely or homesick. This could be attributed to students who did not have far to commute from home, students who had constant contact with their families, or students with less of an attachment with family. The effect of social anxiety is a fair predictor of homesickness and missing family, but it is an even better predictor of the level of social support at college. However, the changes that result can, at times, be stressful for the student, as he or she leaves existing sources of social support behind, i.e., friends and family. Commonly, this stigma of isolation creates feelings of homesickness and the increased desire to return home (Fisher \& Hood, 1987).

Fifty percent $(n=190)$ of students responded that they occasionally to rarely felt lonely/homesick. Possible reasons for not experiencing loneliness or homesickness include students keeping busy with their studies, their jobs, and social activities. For young college students, the transition to college is generally viewed as a positive step in life involving many new opportunities for students. However, this transition is not without its challenges, especially for those students who must move away from home to attend college. This represents a significant change from previous routines and lifestyle, as well as adapting to a completely new environment involving academic, social and residential challenges (Fisher \& Hood, 1987). While initial feelings of homesickness are obviously common for many students, if not all, prolonged feelings of homesickness often prove to be problematic (Urani, et al., 2016).

Eighteen percent $(n=107)$ of student responses indicated that they almost always to frequently felt lonely or homesick. For most students, the transition to college involves many social and psychological challenges, which include leaving the family home, losing past friendships, and establishing a new social and support network (Holahan, Valentiner \& Moos, 1994; Mounts, 2004). Social relations form the basis of social organization and social structure. Burt (1993) showed that persistent feelings of homesickness can lead to a lack of concentration and ability to perform work duties or studies, along with absent-mindedness and cognitive failures. Thus, homesickness in college students is an issue that must be taken seriously, for it can influence one's level of success in adapting to their new lives as college students and adjusting to their new environment (Fisher \& Hood, 1987). The inability to adjust and the persistent loneliness was a sentiment held by one student who indicated: "When I first enrolled in CSUS, I didn't think about how I would be far from my home in LA. During my years at CSUS, I had trouble getting comfortable with my living situation and social life." Another student wrote: "I felt very lonely and alienated not only because I am not a minority, but because I was considerably older than most of the students. I didn't feel a very inclusive, open, friendly feeling while on campus." The lack of connection to the Sac State community was a sentiment held by many. In an open ended survey question, one student wrote: "Although I rushed a sorority my first and only semester at Sac State, I almost always felt like I didn't belong. It could have been that I didn't live on campus as a freshman, or that my core group of friends did not attend school at Sac State, or that I thought I was too cool to be involved, but there was a disconnect between the campus community and me. I never really felt like part of anything on campus." Another student indicated: "Maybe I didn't involve myself in the community but to me I didn't see a place for myself to be a leader or a follower." Hartley's (2011) paradigm of intrapersonal and interpersonal resilience in relation to the ability to cope with change and interact in a social support network demonstrates the need for each and every student to be embraced by the college community. 


\section{Recommendations:}

- Early identification and intervention that address separation issues may lead to increased confidence. These identification efforts should start with educational programs initiated by high school counselors and continued through college.

- Assistance with improving academic and social integration may increase retention of students. Faculty mentoring and small special interest seminars offered by the university can enhance the students' feeling of selfefficacy. Several faculty and student events held throughout the semesters can provide opportunities for essential social interactions so students can feel part of the university, and offer a sense of community.

- Initiative, effort, and persistence are the skills necessary for successful adjustment to new situations, i.e., adjusting to college life. Encourage students to participate in social organizations to help eliminate the feeling of being lonely and/or homesick.

\section{SOCIAL LIFE INTERFERENCE}

While attending Sacramento State, how often did you feel that your social life interfered with your school work?

\section{Figure 11: Social Life Interference}

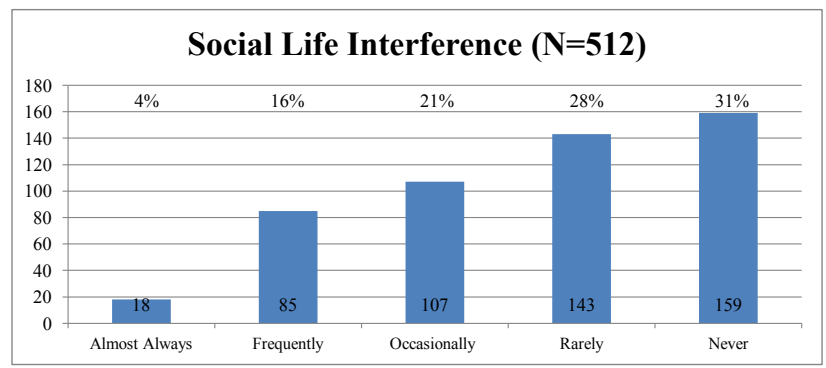

Figure 11 shows that $59 \%(n=302)$ of student responses indicated that they rarely to never had their social life interfere with their school homework. This high response rate is indicative that more than half of the students were able to balance their time spent socializing effectively in order to meet the demands of their courses. However, for some students, the challenge was not balancing their time socializing, but rather making themselves engage socially. For example, one student indicated: "For me, the big thing for me is not to be isolated to be around people more because I am not a sociable person so if I stay isolated I tend to brew on things more than it needs to be." Healthy relations with peers has been described as "the single most important environmental influence on student development" (Astin, 1993), and acts as an academic and personal support network that positively influences students' development (Tierney, Corwin, \& Colyar, 2005).

Balancing the demands of a full course load, extracurricular activities and part-time jobs can become overwhelming to some students. Weidman (1989) was one of the first to argue that a socialization model is necessary to fully understand college impact. Brim (1996) defines socialization, incorporated by Weidman, as "the process by which persons acquire the knowledge, skills, and dispositions that make them more or less effective members of their society." Weidman (1989) stresses the importance of understanding both the individual and the groups and environments that influence the individual. From the individual's point of view, socialization entails learning the appropriate behaviors and attitudes of the group, followed by interactions with others who exemplify the norms of that particular group. An individual learns appropriate social norms according to how group members react. For students, this entails norms regarding primary socialization with faculty and peers, with additional influences from family members and employers.

Twenty one percent $(n=107)$ of student responses indicated that they occasionally had their social life interfere with their school work. This could be indicative of certain occasions such as birthday and holiday celebration that take up significant time around the same time that academic demands are high.

Lastly, 20\% ( $n=103$ ) of responses indicate that students almost always to frequently had their school studies interrupted by their social life. Peer approval among fellow students will make students feel at ease and accepted. However, the reverse can also be applied in being too overly social. This is confirmed in this study, as one student stated: "I simply was not ready to be a college student. All I wanted to do was party and I had no real direction in life. I lacked the motivation to succeed academically in a college setting and needed to take time for self-discovery." Another student indicated: "Unfortunately, I valued (subconsciously) my social relationships out of school more than my academic school work. My social life got in the way of school." When asked the question: What resources would be helpful if you were to return to Sacramento State? One student 
indicated: "I would meet off campus because I lived in the dorm, so I kind of just had really poor study habits. Also I got way into my social life." Another student indicated: "I think I need more "me" time. I am too much of a social person I am always with people and never alone. I have a friend waiting in the car for me right now."

\section{Recommendations:}

- Educate students on how to balance their social activities with their school work. Social engagement with family and friends is important for college students to consider because these networks can serve as potential allies. Students should set their priorities so they can devote time to their friends and family while maintaining a good academic standing.

- The campus should continue to scale up the offering of workshops and resources on time management to give students the tools needed to participate in social activities and keep up with their studies.

\section{WORRIED ABOUT FAMILY}

While attending Sacramento State, how often did you feel worried about family problems?

Figure 11: Worried About Family

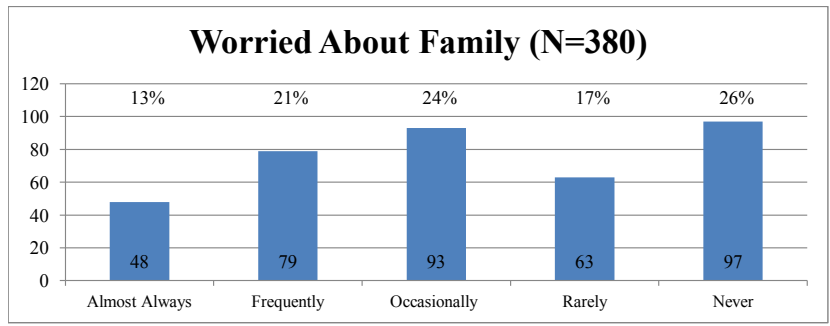

Figure 11 shows that $43 \%(n=160)$ of responses indicated that students rarely to never worried about family issues. The numbers reflect that students who did not put too much emphasis on family issues could indicate that their home environment was satisfactory. Not having to worry about family issues would make it easier for students to concentrate on their studies.

Thirty four percent $(n=127)$ of student responses showed that students almost always to frequently worried about family issues. These responses could be attributed to family issues that occurred while students were attending school. As Revenson and colleagues (2015) suggested, "Major life stressors are not experienced in a social vacuum. When one family member is experiencing ongoing, complex stressors or life strains, other family members are affected." Given the impact of stressors on the family dynamics, studies have shown how family members cope with stressors such as divorce (T. D. Afifi et al., 2006), natural disasters (e.g., W. A. Afifi, Felix, \& T. D. Afifi, 2012), and illness (e.g., Koehly et al., 2008).

When asked the question: What obstacles/challenges did you encounter while attending Sacramento State? Several students experienced negative effects on their social lives or academic performance as they balanced their school and home lives (Schmidt \& Welsh, 2010). Many students indicated that their concern for family was a major obstacle. For example, one student indicated: "My parents were going through a divorce and fighting constantly. It started in my high school year and unfortunately I was only seven miles away north and they brought it to me and I was in the middle and it was just really hard and I still don't know what to do." Another student wrote: "I was going through a lot of family and financial issues at the time I was enrolled at Sac State. My family was falling apart and I was on my own for the very first time. I was not mentally prepared for college."

For other students, family illness was the obstacle. Schmidt and Welsh (2010) focused specifically on the college students' adjustment when a family member was ill and found the adjustment was significantly related to social support and attachment to the family member. For one student, his father's illness made it extremely difficult to adjust: "When I first transferred, I was not prepared for the change in work load. I had no idea that I could've gone to see a tutor on campus, or even talk with a counselor. My father's health has been an obstacle for my college success since day one at Sac State. Learning how to cope with my father's illness and still be a functioning person was extremely difficult and still is."

Another student indicated: "I started in 2013, and was very excited as my first semester went very well. But my mom had heart failure for the first time. So I just couldn't go through it. Sorry I was getting emotional. It was really hard for me to focus because I was at the hospital throughout almost the whole semester that she went through heart transplant surgery." For another student, multiple illnesses and losses were major obstacles: "I started at Sac State in fall 2010. During that time, my grandfather was really sick, and he later passed away. Then, the following year, my great grandma was sick too and passed away on the same day as him but different year. That was really hard on me. Then, I stopped going to Sac State when my cousin just passed away. She had no signs 
of being sick, and we grew up together so it was really hard. Now, every year during Thanksgiving and Christmas it's sad without them, and right before finals and the beginning of the semester it is a constant reminder." Students coping with loss or family issues have lower grade point averages than their peers (Servaty-Seib \& Hamilton, 2006).

Additionally, college students might have difficulty making sense of their different and sometimes conflicting roles as students, employees and family members (Perna, 2010). As one student indicated: "I was experiencing a lot of stress and pressure from home which had affected my education. I came from a very traditional family that valued marriage and fertility more than education. I wish my parents were more understanding about my goals and dreams. They were supportive physically but not emotionally. My mother's constant nagging about marriage made me very stressful because she thinks the older I get, the less likely I would find a good life partner. I worked part time and went to school full time. My parents refused to buy me a car. Instead they drove me to work and school every day that it felt suffocating. Most of the time I was stressed and did not know who I could express my anger, frustration and sadness to. My parent's high expectation also stressed me out because they wanted me to be someone other than myself. I felt like I needed to get away from that kind of environment and tried every way that I could just to be independent." Another student wrote: "My parents not knowing how college worked was an obstacle. Sometimes I had to stay over in Sacramento finishing a project and I kept getting calls from my dad saying he wanted me home. It's hard to explain to them how hard and important college is."

Lastly, $24 \%$ ( $n=93$ ) of responses indicated that students occasionally worried about family issues. These students experienced some form of discord in their family situation which made it difficult, at least sometimes, to concentrate on their studies.

One student indicated: "Many of these feelings stem from my family and other personal obligations and issues. I would sometimes feel as if others thought that everyone else's problems were more important than my own, so my problems would be forced to take a back burner until everyone else's were settled."

\section{Recommendations:}

- Ensure that faculty members are aware of personal issues associated with their students.
- Refer students who are impacted by the personal issues to counselors in order to address such issues to mitigate impact on students' academic performance.

- Continue to encourage counselors to follow-up with students to ensure they are staying on track with their academic studies.

\section{Health Concerns \\ ALCOHOL CONSUMPTION}

While enrolled at Sacramento State, how often did you drink alcohol?

\section{Figure 15: Alcohol Consumption}

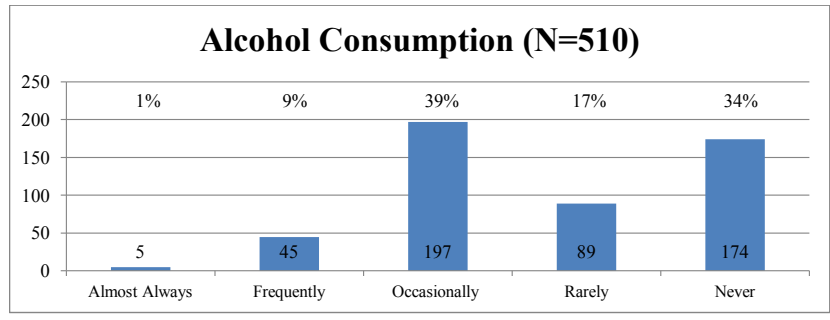

Figure 15 shows that $51 \%(n=263)$ of student responses indicated that students rarely to never used alcohol. Over half of the students who participated in this survey indicated that they did not use alcohol. This could be attributed to being underage for alcoholic purchases. In some instances, this could also be the student's decision not to partake in alcohol consumption.

Some campus alcohol policies enjoy support among college students (DeJong et al., 2007, Saltz, 2007, Wechsler, Lee, Kuo, et al., 2002 and Wechsler, Lee, Nelson and Kuo, 2002). This could be attributed to special events on campus. However, policy support appears to vary by policy content, such that approval rates for a single policy have ranged from $14.6 \%$ (i.e., "Eliminate low-price bar and liquor store promotions targeted to college students.") to $90.1 \%$ (i.e., "Use stricter disciplinary sanctions for students who engage in alcoholrelated violence.") (DeJong et al., 2007). Policies vary by relevance to the average student and also in the underlying message frame (gain, loss, more or less punitive), which may influence support (Dorfman, Wallack, \& Woodruff, 2005).

Thirty nine percent $(n=197)$ of student responses indicated that students occasionally consumed alcohol. The use of alcohol shows that there could be certain situations where students would participate in alcohol consumption. It could be attributed to celebrations, hanging out with friends, or 
as a means for relaxation.

Sac State has a strict no-alcohol policy, and students not adhering to the policy will be held in violation of the established policies. Disciplinary measures will include: "Sanctions for all alcohol policy violations may include parental notification and indicate typical minimum responses for active involvement. Depending on the severity of the violation, sanctioning levels and guidelines can be more aggressive. Educational sanctions are at the discretion of the HRL Conduct Officer. Those being removed from housing will continue to be held to the terms and conditions of their housing contract." This may be why students were reluctant or not willing to provide actual alcohol consumption, particularly since many of them are trying to return to Sacramento State to complete their degrees.

Ten percent $(n=50)$ of student responses indicated that students almost always to frequently consumed alcohol. Since there were low responses in the frequency of alcohol consumption, it is interesting to note that alcohol either occasionally or never played a role in students' lives. Several prospective studies of college students have demonstrated that as they moved out of their parents' homes into dormitories or off-campus living situations, students' drinking increased (e.g., Baer et al., 1995; Harford \& Muthin, 2001). Bachman and colleagues (1997) found that college students (2-and 4-year combined), as compared with their non-college peers, reported lower rates of heavy drinking while in high school; however, their use increased when they enrolled in college, resulting in higher levels than those of their non-college peers. Interestingly, some studies of students indicated that students at 2-year colleges indicate that they drink less than those students attending 4-year colleges (Presley et al., 2002; Sheffield et al., 2005). Drinking in college was often attributed to being immature and not realizing the negative impacts to their academic outcomes. For example, one student indicated: "I was young and stupid with alcohol."

\section{Recommendations:}

- The responses indicated, on the whole, that Sac State students do not partake in alcohol consumption. While this is a good statistic, students should be made aware there is assistance available to them. This can include ensuring that students are aware of campus escorts (Safe Rides) should they be unable to drive themselves home. Stress to students that they can either take a taxi or call Uber if they feel that they have had too much to drink. Designate a sober driver if going out with friends.

- Stress to students the potential effects of alcohol consumption (missing class(es); getting into fights or arguments; drinking and driving), and how it could affect their mental well-being, particularly if they are experiencing depression or other mental health issues.

\section{DRUG/SUBSTANCE ABUSE}

\section{While enrolled at Sacramento State, how often did you use drugs or other substances?}

Figure 16: Alcohol/Substance Abuse y

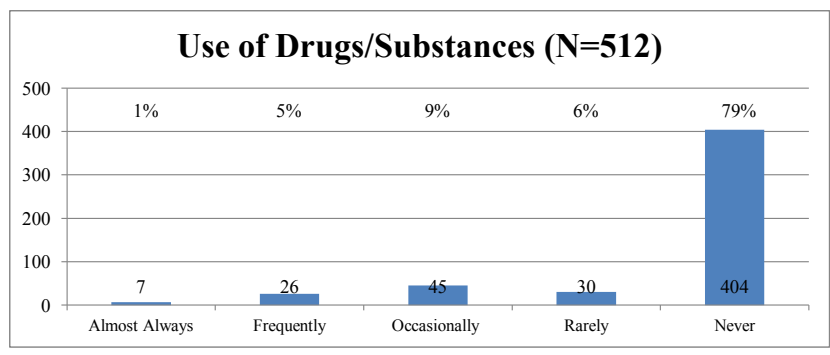

Figure 16 shows that $85 \%(n=434)$ of student responses indicated that students rarely to never used drugs/substances. Student responses indicated that they exercise or participate in other recreational activities in place of turning to drugs/substances as a stress relief outlet.

Six percent $(n=33)$ of responses indicated that students almost always to frequently used drugs/substances. The survey question did not specifically address the type of drugs (recreational/prescription) students consumed. Therefore, it is difficult to come to any real conclusion. As an example of students taking prescription medications, one student indicated: “Bipolar is often linked with substance abuse. I didn't realize I had a problem until it became a serious problem, which was after I stopped attending. I was very functional, only attended class when necessary (listening to teachers drone on isn't interesting or a challenge to me) but still excelled getting very high test scores from reading the textbook. Plus a lot of partying with friends, not other students."

Nine percent $(n=45)$ of student responses indicated that students occasionally used drugs/substances. Increases in substance use have been most often identified for those young adults who move away from their parents' homes to attend college (White et al., 2005). Increases in alcohol and marijuana use for college students were attributed to living in dormitories or similar housing shared with other young adults (Crowley, 1991). When asked the question: 
What obstacles/challenges did you encounter while attending Sacramento State? One student indicated: “Drugs and alcohol were huge obstacles while attending Sac State, as was a very toxic relationship with a fellow student." Another student indicated: "Smoked marijuana daily." For other students, they differentiated their use of prescribed drugs from recreational drugs. For example, one student indicated: "I have to take prescription medications and therapeutic treatments; however I try not to take them while on campus or driving. I also do meditative yoga." Another student indicated: "Medical Cannabis for scleroderma joint pain and pulmonary arterial hypertension (high blood pressure in the arteries of the lungs). HOWEVER - I always take this at night, after homework - never at school." These student responses are indicative of prescribed medications. The low number of students reporting to have consistently consumed illegal drugs or prescribed medications would indicate that drug use was not problematic on the campus. However, the issue should still be addressed to account for incidences where students were reluctant to reveal such use, particularly as many of the students in this study are trying to return to Sacramento State.

\section{Recommendations:}

- Sac State students who are found to be in possession of drugs can have the sanctions previously described levied against them. Continue to provide students with guidance counselors and medical intervention should they require assistance in quitting the use of drugs. Inform students of their academic standing, i.e., suspension, should they continue the use of drugs and/ or controlled substances. Encourage students to access a substance abuse treatment program, and require a workshop on the effects of drugs and risks of abuse and addiction, or community service as an alternative, first form of punishment.

- Inform students of the long term health effects or mortality of using drugs and encourage changing attitudes with techniques such as self-esteem enhancement through events and by increasing awareness of the available wellness programs offered by The WELL.

\section{AUTHORS AND CONTRIBUTORS}

Dr. Carlos Nevarez, Professor and Research Consultant

Katrina Pimentel, Research Assistant

Dr. Marcellene L. Watson-Derbigny, Associate Vice President, Student Retention and Academic Success

CeCe Krek, Research Assistant

We want to express our deepest gratitude to CeCe Krek for coming out of retirement temporarily for her assistance with the development of this report.

The authors wish to thank Bernard Reyes, Abraham Madrigal, and Sally Monical for their support in the collection of data and literature.

\section{ACKNOWLEDGMENT}

This publication is based on a project funded in part by CSU Chancellor's Office Graduation Initiative, and the Division of Student Affairs, Student Academic Success \& Educational Equity Programs (SASEEP). 


\section{References}

Afifi, T. D., Hutchinson, S., \& Krouse, S. (2006). Toward a theoretical model of communal coping in post divorce families and other naturally occurring groups. Communication Theory, 16(3), 378-409.

Afifi, W. A., Felix, E. D., \& Afifi, T. D. (2012). The impact of uncertainty and communal coping on mental health following natural disasters. Anxiety, Stress \& Coping, 25(3), 329-347.

Astin, A. W. (1993). An empirical typology of college students. Journal of college student development.

Astin, A. W., \& Oseguera, L. (2005). Pre-college and institutional influences on degree attainment. College student retention: Formula for student success, 245-276.

Avery, C., \& Hoxby, C. M. (2004). Do and should financial aid packages affect students' college choices?. In College choices: The economics of where to go, when to go, and how to pay for it (pp. 239-302). University of Chicago Press.

Bachman, J. G., Wadsworth, K. N., O'Malley, P. M., Johnston, L. D., \& Schulenberg, J. E. (2013). Smoking, drinking, and drug use in young adulthood: The impacts of new freedoms and new responsibilities. Psychology Press.

Baer, J. S., Kivlahan, D. R., \& Marlatt, G. A. (1995). High『risk drinking across the transition from high school to college. Alcoholism: Clinical and Experimental Research, 19(1), 54-58.

Barrios, L. C., Everett, S. A., Simon, T. R., \& Brener, N. D. (2000). Suicide ideation among US college students associations with other injury risk behaviors. Journal of American College Health, 48(5), 229-233.

Beck, B. L., Koons, S. R., \& Milgrim, D. L. (2000). Correlates and consequences of behavioral procrastination: The effects of academic procrastination, self-consciousness, self-esteem and self-handicapping. Journal of Social Behavior and Personality, 15(5), 3.

Blanco, C., Okuda, M., Wright, C., Hasin, D. S., Grant, B. F., Liu, S. M., \& Olfson, M. (2008). Mental health of college students and their non-college-attending peers: results from the National Epidemiologic Study on Alcohol and Related Conditions. Archives of general psychiatry, 65(12), 1429-1437.

Bodenmann, G. (1997). A Swiss replication of Gottman's couple typology. Swiss Journal of Psychology, 56(4), 205-216.

Brim Jr, O. G. (1966). Socialization through the life cycle. In 0. G. Brim, Jr., and S. Wheeler (Eds), Socialization after childhood: Two essays (pp. 1-49).

Broadbridge, A., \& Swanson, V. (2005). Earning and learning: how term冈time employment impacts on students' adjustment to university life. Journal of Education and Work, 18(2), 235-249.

Burka, J. B., \& Yuen, L. M. (1983). Procrasrinationt Why you do it and what to do about it. Reading, PA: Addison-Wesley.

Burt, C. D. (1993). Concentration and academic ability following transition to university: An investigation of the effects of homesickness. Journal of Environmental Psychology, 13(4), 333-342.
Callender, C. (2008). The impact of term凶time employment on higher education students' academic attainment and achievement. Journal of Education Policy, 23(4), 359-377.

Castillo, L. G., \& Schwartz, S. J. (2013). Introduction to the special issue on college student mental health. Journal of clinical psychology, 69(4), 291-297.

Cauffman, E., \& Steinberg, L. (1995). Cognitive and Affective Influences on Adolescent Decision-Making, The. Temple $L$. Rev., 68, 1763.

Chaloupka, F. J., Grossman, M., \& Saffer, H. (2002). The effects of price on alcohol consumption and alcohol-related problems. Alcohol research and health, 26(1), 22-34.

Chemers, M. M., Hu, L. T., \& Garcia, B. F. (2001). Academic selfefficacy and first year college student performance and adjustment. Journal of Educational psychology, 93(1), 55.

Corrigan, P. W., \& Wassel, A. (2008). Understanding and influencing the stigma of mental illness. Journal of psychosocial nursing and mental health services, 46(1), 42-48.

Covington, M. V. (1993). A motivational analysis of academic life in college. In J. Smart (Ed.), Higher Education: A handbook of theory and research (pp. 50-93). New York, NY: Agathon.

Crowley, J. E. (1991). Educational status and drinking patterns: How representative are college students?. Journal of studies on alcohol, 52(1), 10-16.

Cureton, J. S., \& Levine, A. (1997). Student politics: The new localism. The Review of Higher Education, 21(2), 137-150.

Czyz, E. K., Horwitz, A. G., Eisenberg, D., Kramer, A., \& King, C. A. (2013). Self-reported barriers to professional help seeking among college students at elevated risk for suicide. Journal of American College Health, 61(7), 398-406.

DeJong, W., Towvim, L. G., \& Schneider, S. K. (2007). Support for alcohol-control policies and enforcement strategies among US college students at 4-year institutions. Journal of American College Health, 56(3), 231-236.

DesJardins, S. L. (2001). Assessing the effects of changing institutional aid policy. Research in Higher Education, 42(6), 653-678.

DesJardins, S. L., Ahlburg, D. A., \& McCall, B. P. (2006). An integrated model of application, admission, enrollment, and financial aid. Journal of Higher Education, 381-429.

Dorfman, L., Wallack, L., \& Woodruff, K. (2005). More than a message: Framing public health advocacy to change corporate practices. Health Education \& Behavior, 32(3), 320-336.

Downs, M. F., \& Eisenberg, D. (2012). Help seeking and treatment use among suicidal college students. Journal of American College Health, 60(2), 104-114.

Eisenberg, D., Golberstein, E., \& Gollust, S. E. (2007). Helpseeking and access to mental health care in a university student population. Medical care, 45(7), 594-601. 
Farrell, E. (2002). A suicide and its aftermath. The Chronicle of Higher Education, 48(7), 37-40.

Ferrari, J. R. (1991). Self-handicapping by procrastinators: Protecting self-esteem, social-esteem, or both? Journal of Research in Personality, 25(3), 245-261.

Ferrari, J. R. (1994). Dysfunctional procrastination and its relationship with self-esteem, interpersonal dependency, and self-defeating behaviors. Personality and Individual Differences, 17(5), 673-679.

Ferrari, J. R. (2001). Procrastination as self-regulation failure of performance: Effects of cognitive load, self-awareness, and time limits on "working best under pressure." European Journal of Personality, 15, 361-406.

Fisher, S., \& Hood, B. (1987). The stress of the transition to university: a longitudinal study of psychological disturbance, absent-mindedness and vulnerability to homesickness. British Journal of Psychology, 78(4), 425-441.

Gallagher, R. P., \& Gill, A. (2004). National survey of counseling center directors. Alexandria, VA: International Association of Counseling Services.

Gruenewald, P. J., Millar, A. B., Treno, R. J., Yang, Z., Ponicki, W. R., \& Roeper, P. (1996). The geography of availability and driving after drinking. Addiction, 91(7), 967-983.

Haas, A. P., Hendin, H., \& Mann, J. J. (2003). Suicide in college students. American Behavioral Scientist, 46(9), 1224-1240.

Hamilton, L. A., \& Servaty-Seib, H. L. (2006). Educational performance and persistence of bereaved college students. Journal of College Student Development, 47(2), 225-234.

Harford, T. C., \& Muthén, B. O. (2001). Alcohol use among college students: the effects of prior problem behaviors and change of residence. Journal of Studies on Alcohol, 62(3), 306-312.

Hartley, M.T. (2011). Examining the relationships between resilience, mental health, and academic persistence in undergraduate college students. Journal of American College Health, 59(7), 596-604.

Hearn, J. C. (2001). The paradox of growth in federal aid for college students, 1960-1990. The finance of higher education: Theory, research, policy, and practice, 267-320.

Heller, D. E. (1997). Student price response in higher education: An update to Leslie and Brinkman. Journal of higher education, 624-659.

Heller, D. E. (1999). The effects of tuition and state financial aid on public college enrollment. The Review of Higher Education, 23(1), 65-89.

Holahan, C. J., Valentiner, D. P., \& Moos, R. H. (1994). Parental support and psychological adjustment during the transition to young adulthood in a college sample. Journal of Family Psychology, 8(2), 215.
Holmes, V. (2008). Working to live: Why university students balance full-time study and employment. Education \& Training, 50, 305-314.

Hoyt, J. E., \& Winn, B. A. (2004). Understanding retention and college student bodies: Differences between drop-outs, stop-outs, opt-outs, and transfer-outs. NASPA Journal, 41(3), 395-417.

Hunt, J., \& Eisenberg, D. (2010). Mental health problems and help-seeking behavior among college students. Journal of Adolescent Health, 46(1), 3-10.

Hunt, J. B., Watkins, D., \& Eisenberg, D. (2012). How do college campuses make decisions about allocating resources for student mental health?: Findings from key participant interviews. Journal of College Student Development, 53(6), 850-856.

Kadison, R., \& DiGeronimo, T. F. (2004). College of the overwhelmed: The campus mental health crisis and what to do about it. Jossey-Bass.

Keyes, K. M., McLaughlin, K. A., Koenen, K. C., Goldmann, E., Uddin, M., \& Galea, S. (2012). Child maltreatment increases sensitivity to adverse social contexts: neighborhood physical disorder and incident binge drinking in Detroit. Drug and alcohol dependence, 122(1), 77-85.

Kessler, R. C., Foster, C. L., Saunders, W. B., \& Stang, P. E. (1995). Social consequences of psychiatric disorders, I: Educational attainment. American journal of psychiatry, 152(7), 1026-1032.

Koehly, L. M., Peters, J. A., Kuhn, N., Hoskins, L., Letocha, A., Kenen, R., ... \& Greene, M. H. (2008). Sisters in hereditary breast and ovarian cancer families: communal coping, social integration, and psychological well $₫$ being. Psycho® Oncology, 17(8), 812-821.

Krumrei, E. J., \& Newton, F. B. (2009). The puzzle of college students success: Fitting the counseling and advising pieces together. National Academic Advising Association Clearinghouse of Academic Advising Resources. Retrieved from http://www.nacada.ksu.edu/Clearinghouse/M02/ Counsel.htm

Krumrei-Mancuso, E. J., Newton, F. B., Kim, E., \& Wilcox, D. (2013). Psychosocial factors predicting first-year college student success. Journal of College Student Development, 54(3), 247-266.

Kuh, G. D., Pace, C. R., \& Vesper, N. (1997). The development of process indicators to estimate student gains associated with good practices in undergraduate education. Research in higher education, 38(4), 435-454.

Kulm, T. L., \& Cramer, S. (2006). The relationship of student employment to student role, family relationships, social interactions and persistence. College Student Journal, 40(4), 927.

Lavigne, A. M., Witt, C. F., Wood, M. D., Laforge, R., \& DeJong, W. (2008). Predictors of college student support for alcohol control policies and stricter enforcement strategies. The American journal of drug and alcohol abuse, 34(6), 749-759. 
Lay, C. H. (1995). Trait procrastination, agitation, dejection, and self-discrepancy. In Procrastination and Task Avoidance (pp. 97-112). Springer US.

Lyons, R. F., Mickelson, K. D., Sullivan, M. J., \& Coyne, J. C. (1998). Coping as a communal process. Journal of Social and Personal Relationships, 15(5), 579-605.

McPherson, M. S., \& Schapiro, M. O. (2006). US higher education finance. Handbook of the economics of education, 2 , 1403-1434.

Mehta, S.S., Newbold, J.J., \& O'Rourke, M.A. (2011). Why do first-generation students fail? College Student Journal, 45(1), 20-35.

Mehta, M.A. (2011) Commentary: The only way is down. Augmented deactivation of the default mode network by increased catecholamine transmission - a general mechanism? Reflections on Liddle et al.). Journal of Child Psychology and Psychiatry 52(7), 772-773.

Moore, R. L., Studenmund, A. H., \& Slobko, T. (1991). The effect of the financial aid package on the choice of a selective college. Economics of Education Review, 10(4), 311-321.

Mortimer, J.T., Finch, M, Dennheny, K., Lee, C., \& Beebe, T. (1994). Work experience in adolescence. Journal of Vocational Educational Research, 19, 39-70.

Mounts, N. S. (2004). Contributions of parenting and campus climate to freshmen adjustment in a multiethnic sample. Journal of Adolescent Research, 19(4), 468-491.

National Center for Educational Statistics, U.S. Department of Education. (2012).IPEDS data feedback report 2012: California State University Sacramento. http://www.csus.edu/ oir/Data\%20Center/IPEDS\%20Reports/2012_IPEDS_FeedbackReport.pdf

Nolan, J. M., Ford, S. J., Kress, V. E., Anderson, R. I., \& Novak, T. C. (2005). A comprehensive model for addressing severe and persistent mental illness on campuses: The new diversity initiative. Journal of College Counseling, 8(2), 172-180.

Paulsen, M. B., \& St John, E. P. (2002). Social class and college costs: Examining the financial nexus between college choice and persistence. The Journal of Higher Education, 73(2), 189-236.

Perna, L. W., Walsh, E., \& Fester, R. (2010). Promoting the Educational Attainment of Adults: The Potential Role of YouthOriented Precollege Outreach Programs. Educational Policy, 0895904810386599.

Porter, M. E. (1990). The competitive advantage of notions. Harvard business review, 68(2), 73-93.

Presley, C.A. (2004). Vineyard GM. Core Alcohol and Drug Survey User's Manual. 7th ed. Carbondate, IL, Core Institute.

Revenson, T. A., \& Hoyt, M. A. (2015). Chronic Illness and Mental Health. Encyclopedia of Mental Health, 284.
Robbins, S.B., Allen, J., Casillas, A., Peterson, C.H., \& Le, H. (2006).

Unraveling the differential effects of motivational and skills, social, and self-management measures from traditional predictors of college outcomes. Journal of educational psychology, 98(3), 598.

Robotham, D. (2009). Combining study and employment: a step too far?. Education+ Training, 51(4), 322-332.

Saltz, R. F. (2007). How do college students view alcohol prevention policies?. Journal of Substance Use, 12(6), 447-460.

Schneider, M., \& Yin, L. (2011). The High Cost of Low Graduation Rates: How Much Does Dropping Out of College Really Cost?. American Institutes for Research.

School of Public Health College Alcohol Study surveys: 19932001. Journal of American college health, 50(5), 203-217.

Sheffield, F. D., Darkes, J., Del Boca, F. K., \& Goldman, M. S. (2005). Binge drinking and alcohol-related problems among community college students: implications for prevention policy. Journal of American College Health, 54(3), 137-141.

Schmidt, C. K., \& Welsh, A. C. (2010). College Adjustment and Subjective Well囚Being When Coping With a Family Member's Illness. Journal of Counseling \& Development, 88(4), 397-406.

Scribner, R. A., MacKinnon, D. P., \& Dwyer, J. H. (1994). Alcohol outlet density and motor vehicle crashes in Los Angeles County cities. Journal of studies on alcohol, 55(4), 447-453.

Stewart, K.D., \& Bernhardt, P.C. (2010). Comparing millennials to pre-1987students and with one another. North American Journal of Psychology, 12(3), 579-602.

St. John, E. P. (2006). Contending with financial inequality: Rethinking the contributions of qualitative research to the policy discourse on college access. American Behavioral Scientist, 49(12), 1604-1619.

St. John, E.P., Daun-Barnett, N., and Moronski-Chapman, K.M. (2013). Public policy and higher education : reframing strategies for preparation, access, and college success. Routledge, Taylor \& Francis Group.

Stone, G. L., \& Archer, J. (1990). College and University Counseling Centers in the 1990s Challenges and Limits. The Counseling Psychologist, 18(4), 539-607.

Swanson, V., Broadbridge, A., \& Karatzias, A. (2006). Earning and learning: Role congruence, state/trait factors and adjustment to university life. British Journal of Educational Psychology, 76(4), 895-914.

Tierney, W. G., Corwin, Z. B., \& Colyar, J. E. (2005). Preparing for college: Nine elements of effective outreach. SUNY Press.

Twenge, J. M., Gentile, B., DeWall, C. N., Ma, D., Lacefield, K., \& Schurtz, D. R. (2010). Birth cohort increases in psychopathology among young Americans, 1938-2007: A crosstemporal meta-analysis of the MMPI. Clinical psychology review, 30(2), 145-154.

Twenge, J. M. (2011). Generational differences in mental health: are children and adolescents suffering more, or less?. American journal of orthopsychiatry, 81(4), 469. 
Urani, M. A., Miller, S. A., Johnson, J. E., \& Petzel, T. P. (2003). Homesickness in socially anxious first year college students. College Student Journal, 37(3), 392-400.

Wechsler, H., Kuo, M., Lee, H., \& Dowdall, G. W. (2000). Environmental correlates of underage alcohol use and related problems of college students. American journal of preventive medicine, 19(1), 24-29.

Wechsler H., Lee, J. E., Kuo, M. Seibring, and T.F. Nelson, H. L. (2002). Trends in college binge drinking during a period of increased prevention efforts. Findings from 4 Harvard school of public health college alcohol study surveys: 1993-2001. Journal of American College Health, 50 (2002), pp. 203-217.

Weidman, J. C. (1989). The world of higher education: A socialization-theoretical perspective.

Weitzman, E. R., Folkman, A., Folkman, M. P., \& Wechsler, H. (2003). The relationship of alcohol outlet density to heavy and frequent drinking and drinking related problems among college students at eight universities. Health \& Place 9:1-6.

Westefeld, J. S., Homaifar, B. H., Spotts, J., Furr, S., Range, L., \& Werth, J. L. (2005). Perceptions concerning college student suicide: Data from four universities. Suicide and Life Threatening Behavior, 35, 640-645.

White, H. R., Labouvie, E. W., \& Papadaratsakis, V. (2005). Changes in substance use during the transition to adulthood: $A$ comparison of college students and their noncollege age peers. Journal of Drug Issues, 35(2), 281-306.

Zax, M., \& Specter, G. A. (1974). An introduction to community psychology. John Wiley \& Sons. 
